\title{
WTO Agreement on Agriculture: A Developing Country Perspective
}

\author{
Xiaozhen Li \\ China Development Bank Guangxi Branch, Nanning 530000, China \\ Tel: 86-771-382-2571_E-mail: lixiaozhen1@hotmail.com \\ Wei Wang \\ Guangxi Seismological Bureau, Nanning 530022, China \\ Tel: 86-771-283-6391_E-mail: angela_ww82@hotmail.com
}

\begin{abstract}
This article critically assesses the extent to which the WTO takes into consideration the interests of developing nations, by reference to the Agreement on Agriculture.
\end{abstract}

Keywords: The Agreement on Agriculture, Special and differential treatment, Developing countries.

\section{Introduction}

Three-quarter poorest people of the world live in rural areas, the proportion in the developing countries being as high as $96 \%$. It means that the agriculture is an urgent and vital problem for developing countries, and it is important to sustainable development, which includes poverty alleviation, economic growth and food security.

The Uruguay Round Agreement on Agriculture (AoA) came into force on 1 July 1995 and is to be implemented over a six-year period ending 31 December 2000 for developed countries and over a ten-year period ending 31 December 2004 for developing countries. The AoA called for the conversion of non-tariff barriers on agricultural products to tariffs as well as their reduction. It also called for cuts to both domestic support subsidies and export subsidies. Developing countries had a more relaxed schedule of reductions, and the Least Developed Countries were exempt from these cuts.

It considered the interests of developing countries to some extent and provides them with the special and differential treatment. However, world agriculture trade still remains heavily distorted. On the one hand, some rich countries keep on protecting their producers by domestic supports and export subsides. On the other hand, they force developing countries open markets as agriculture trade liberalization. It can be seen that the AoA is not a really fair agreement to developing countries.

This article will discuss following questions: First, the special and differential treatment in the AoA for developing countries and the effect. Second, limits to special and differential treatment in the AoA. Third, some reforms which should be considered in Doha Round.

\section{The special and differential treatment for developing countries and the effect}

\subsection{Special and differential treatment for developing countries.}

Under the AoA, special and differential treatment is provided for developing countries. Developing countries may implement the agreement over a period of up to ten years and, in general, the reduction commitments in each area of the agreement for developing countries are two-thirds of those for developed countries. The special and differential treatment covers three main issues related to agriculture:

- Market access.

The AoA has a twofold aim: improve the transparency of existing protection measures and facilitate their reduction, and open domestic markets to more imports.

Developed countries are to cut bound tariffs by $36 \%$ over six years, and developing countries are to make $24 \%$ cuts over ten years. These are average cuts for all agricultural products; however, a minimum reduction of $15 \%$ for developed countries and $10 \%$ for developing countries is required for each product.

A minimum import threshold is stipulated for each sector of agricultural production where there are non-tariff barriers. This was set at 3\% of domestic consumption in 1995 and is increased progressively to $5 \%$ by 2000 (4\% by 2004 for developing countries). 
- $\quad$ Domestic support.

The types of support included in amber box are calculated using the Aggregate Measurement of Support (AMS) and are subject to reduction. Developed countries must reduce this support by $20 \%$ over six years and developing countries by $13.3 \%$ over 10 years.

Under the de minimis rule, countries are exempted from reducing product-specific support that does not exceed 5\% of the total value of production of that product ( $10 \%$ for developing countries) and non-product-specific support that does not exceed $5 \%$ (10\% for developing countries) of the value of total agricultural output.

Developing countries are also exempted from reducing support for agricultural investment, input subsidies for low-income farmers and support to encourage diversification from growing illicit crops. These types of support are allowed under special and differential treatment.

- Export subsidies.

The AoA aims to cut export subsidies. The agreement requires developed countries to cut the value of export subsidies by $36 \%$ and to reduce the volume of subsidized exports by $21 \%$ over six years.

Developing countries must reduce the value of subsidies by $24 \%$ and volume of subsidized exports by $14 \%$ over ten years. Because of developing countries' higher marketing costs, subsidies to reduce the costs of marketing and transporting exports both domestically and internationally are excluded. (See Table 1)

\subsection{The disappointing effect of the AoA.}

Developing countries were supposed to see a rising share of global agricultural exports as a result of the market access provisions. But the Global South's share of agricultural trade has remained steady at around 36\% since the agreement was implemented, and their share of agricultural exports to developed countries has remained at $22.4 \%$ between 1990-1991 and 2000-2001 (Aksoy M. Ataman, 2005, pp.220).

At the same time that their share in global agricultural trade did not increase as expected, the developing countries experienced import surges, flooding their domestic markets with cheap, subsidized imported products from developed countries (FAO, 2006). Although all members were required to liberalize agricultural trade, many developing countries, especially the poorest ones, had already substantially liberalized their agricultural sectors under programs of structural adjustment in the 1980s (Jennifer Clapp, 2006). Under the AoA the developing countries made cuts that were on average greater than the cuts made in developed countries (Anderson, Kym and Will Martin, 2005, pp.263). The result is that developing countries were left much more vulnerable. This has meant that even though the rich countries were required to make steeper tariff cuts than the developing countries, they started from a much higher level and it was not enough to eliminate the inequality. Rather than level the playing field, the AoA made it more steeply stacked against developing countries. The effects on small peasant farmers, whose very livelihoods have been threatened by competition from cheap subsidized imports, have been particularly serious.

It can be seen that such favourable provisions are not as effective as developing countries' anticipation. It is because the provisions of the AoA are unfair to developing countries in fact. In other words, it has never done enough in considering the interests of developing countries.

\section{Limits to special and differential treatment in the AoA}

The vast majority of special and differential treatment in the AoA fails to address their purported objectives efficiently. This disappointed result is causes by two reasons: first, some provisions in the AoA give developed countries the chance to keep promises unconsummated. Second, although there are favourable provisions for developing countries, there are still some troubles for them to fulfill their obligations.

\subsection{The unconsummated promises of developed countries.}

The developing countries have not achieved their anticipation in the AoA. The most important reason is developed countries did not carry out their promises in deed.

- Market access.

The main expectation of developing countries for Uruguay Round is that developed countries could open their markets, at least in agriculture field which has being highly protected. To be disappointed, this expectation did not come true. The actual situation is distorted as follows:

First, under the tariffication commitments of the AoA the WTO members have to convert most non-tariff barriers to tariff on agricultural imports and declare upper bounds for tariff rates. Most developed countries take advantage of such 'convert' to collect high tariff, which is even higher than non-tariff barriers in equivalent effectiveness. Although tariffication appears to be a significant step forward, in most developed countries average agricultural tariffs are higher than non-agricultural tariffs, with rates on some agricultural products exceeding 500\% (OECD 2001). 
Second, they use 'special safeguard measure' acclimatize themselves to such transition in order to protect their farmers. The special agricultural safeguard was designed to address disturbances in domestic markets arising from the removal of non-tariff measures, either in terms of a surge in imports or a decline in domestic prices. However, the modest use of special safeguards suggests that countries' concerns regarding import surges for tariffied commodities were not warranted. That means they will take some restrictive measures as long as the volume of imports exceeds a trigger level or the price of the imported product falls below a trigger price.

Third, although there were minimum cuts to the levels of tariffs which should be reduced, the reductions were averaged, and in practice they were very different for each product. This meant that tariffs on some key products were reduced by very little in practice, especially where there were high tariff peaks to begin with. In addition, food aid was exempted from the export subsidy reductions. It leads that the tariff cut of some farm products, which have potential benefit to developed countries, is remaining on a very low level. For example, on the first year of the AoA has being in operate, the tariffs of some developed countries reached very high rates, such as American (sugar 224\%, peanut 174\%), EU countries (beef 213\%, wheat 168\%), Japan (wheat 353\%) and Canada (butter 360\%, eggs 236\%) (World Trade Report, 2003). In terms of provisions in the AoA, developed countries only need to reduce tariff by $36 \%$ at the end of 2000 , accordingly, the tariffs of some products is stayed on a forbidden high level.

Fourth, the very high tariffs occur on products also has quota restrictions. Broadly, in-quota imports face a zero or low tariff but any potential imports above the quota can face a prohibitive tariff. Take US as an example: beef $26.4 \%$; dairy products from $26 \%$ to $145.2 \%$ according to product; sugar up to $140 \%$; peanuts $139.8 \%$; tobacco $350 \%$, and cotton up to $34.9 \%$. The average out-of-quota tariff is $53 \%$ (WTO, 2005). The evidence indeed suggests that the current US barriers hit the developing countries, especially very poorest countries. A joint IMF/World Bank paper concludes, "The results suggest that EU protection is heavily skewed against imports from middle-income developing countries, and US protection against imports from LDCs.”(IMF/WB paper, 2002)

\section{- Domestic support.}

In terms of provisions in the AoA, developed countries should cut their domestic support on agriculture. However, the sum of such support is increasing.

Developed countries must reduce domestic support by $20 \%$ during 1995 to 2000 . But the supports which included in green and blue boxes are exempted from cuts and there was no limit placed on them. In addition, the US and EU insisted on a 'Peace Clause', which prohibited any challenges to subsidies levels until January 1, 2004, to give the members time to adjust their policies. In this way, developed countries cut the supports in amber box and added lots of the supports in green and blue boxes at the same time. For example, the farmers who live on poultry feed in US and EU have not received support from governments directly. However, the corn for feeding poultry is in the scope of domestic support. Such indirect support brings African farmers into trouble and leads increasing of the sum of domestic support. It is claimed that such supports which developed countries are using can not distort trade. But in fact, they may make farmers able to sell their products in a lower price than those who do not have such supports.

According to the statistic of OECD, the equivalence of domestic supports of all developed countries has being increased from 247 billion dollars in basic period to 174 billion dollars in 1998. In EU countries, the number has being increased from 99.6 billion dollars in basic period to 129.8 billion dollars. In US, it increased from 41.4 billion dollars to 46.9 billion dollars during the same period. And from basic period to 1999, the Total Support Estimate (TSE) of OECD countries was increasing from 276 billion dollars to 326 billion dollars.

The effect of such domestic support appears to have particularly adverse effects for developing countries. For example, the support of US to its domestic cotton industry would lead to a rise in world prices of at least $25 \%$. On this basis, it is estimated that the US support cost the poor cotton-producing countries about 250-300 million dollars in lost export revenue and GDP (IMF/ World Bank, 2002).

- $\quad$ Export subsidies.

According to the provisions of export subsidies in the AoA, at the end of 2000 , developed countries need to cut $36 \%$ of export subsidies of period time. That means they can still keep $64 \%$ of original export subsidies.

Developing countries have the desire to cancel export subsidies, however, it is hard to implement. For example, EU still holds $90 \%$ of the export subsidies of the world. Although the proportion of export subsidies reduced from $31 \%$ to $14 \%$ during 1990 to 1999 , it is only one aspect of problem. During the same period, the common agriculture policy payout went up from 24.9 billion dollars to 39.5 billion dollars. Therefore, the export subsidies only declined one third but not $55 \%$.

In addition, some measures, which are taken by developed countries, have similar effects as export subsidies, such as export credit, export credit guarantee and export insurance. For example, the US offers more support to exports through export credits than any other country. The OECD calculates that nearly $90 \%$ of the subsidy value of export credit 
programmes is from the US programme (compared to 7\% from the EU). Such measures boost import as well but do not need to be cut. Developed countries may cut export subsidies as commitment on the one hand and increase such measures on the other hand. However, developing countries do not have resources to execute these measures.

European Committee agreed that the high export subsidies had already leaded to the long-term overproduction. It disturbs export markets which do not obtain the subsidies in developing countries and causes the export dumping. For example, Indonesia has accused the US of dumping flour on its market, with detrimental effects on Indonesian rice production. A recent surge in US grain exports to Nigeria has hit local production of cereal substitutes, such as cassava and rice. It is alleged by Kenyan government that US dumping of wheat in Egypt lies behind a surge in Kenyan imports of very cheap Egyptian flour, which has had adverse consequences for Kenyan wheat farmers. These examples show that US subsidies for domestic cereal production can have detrimental effects not only on cereal producers in developing countries but also on producers of substitutes for cereals, such as rice.

\subsection{The troubles brought by the AoA to developing countries.}

Although developed countries have not complied with their promises, they keep on bringing pressures to developed countries to implement import and trade liberalization. However, in course of implementing the provisions in the AoA, more and more troubles present to developing countries. The high costs are hard to afford and the complexity of adapting domestic policies with provisions in AoA is a big problem. Further more, the special and differential treatment provided by the AoA for developing countries is not as effective as they anticipated.

\section{- Market assess}

First, the actual implementation of transition from non-tariff barriers to tariff is not very easy for developing countries.

(1) Many developing countries do not have non-tariff barriers, which can convert into equivalent tariff. Thereby, they cannot make use of the equivalent high tariff to protect their farmers like developed countries.

(2) In a considerable number of developing countries, government mandated import monopolies or state trading enterprises still control significant share of imports (mostly essential food items) (Prema-chndra ATHUKORALA, 2007, $p p .877-897)$. It is difficult to establish the frame of domestic law to accord with provisions in the AoA during a short period.

(3) Most of developing countries are highly dependent on agriculture produce and imports. In most of African developing countries, the agriculture import proportion is $20 \%$ to $50 \%$ of total imports. In Latin America the proportion is $18 \%$ to $32 \%$ (Prema-chndra ATHUKORALA, 2007, pp. 897). As the necessity result of the abolishment of non-tariff barriers, the price of agriculture products, especially food, will rise. It will bring a serious negative impact to developing countries.

Second, the aim of tariffication is to achieve trade liberalization, in which is deemed to have an active effect on poverty alleviation and economic growth. In terms of such theory, developing countries have to cut their tariffs. In fact, Bengal have cut its tariff from 102\% in 1988 to $27 \%$ in 1996, Ghana; Kenya and Tanzania cut more than a half tariff in 1990s, and the average tariff of Peru in 1991 was only one third of that in 1989. However, we have not seen any return for those countries until now. That because the advantage of liberalization bases on following conditions: the stabilization of macroeconomics (including exchange rate and income of exports), the high efficiency of market institution (such as competition, credit and basic establishment) and interior reallocate mechanism (such as safety net). But in the real world, developing countries cannot fulfill such conditions.

Third, open market causes increasing of import and shake of price in developing countries. However, the AoA does not provide developing countries with the facility which can protect them from those negative effects. Only a few developing countries can use special safeguard measure because it can only be used on products of tariffication and only nine members in WTO have the right to apply this provision.

The measures of anti-subsidy and anti-dumping are sometimes suggested to be the instead way of special safeguard measure. However, these measures cannot offer any resolvent. The first reason is the aims of these measures are different: special safeguard measure is for temporary wave of price; meanwhile the anti-subsidy and anti-dumping measures are for the distortion of trade. The second reason is that most developing countries are in defect of professional law knowledge and technical framework to startup anti-subsidy and anti-dumping measures which need a high cost. As a result it is unable to prove the damage made by subsidy or dumping. The last reason is that such measures are only applied to some limited dumping actions because of the exception made by developed countries during the negotiation.

\section{- Domestic support and Export subsidies.}

First, unlike developed countries, developing countries did not have domestic support or export subsidies as much as developed countries. In terms of provisions in the AoA, developing countries are forbidden to add or increase de minimis domestic support and use export subsidies. The scope of supports which are free of cut is very narrow and only 
half of developing countries are using such supports. Obviously, it is unfair that the countries which own high supports can keep most of their supports and even increase them because of some defects of the AoA, meanwhile, the countries which have the low supports or no support are forbidden to afford subsidies more than de minimis level.

Second, the special and differential treatment is not as effective as it seems like.

(1) The lower reduction commitments in domestic support and export subsidy of developing countries are good for a few countries, which have budget to use such measures. However, most developing countries can not make use of them. The higher de minimis percentage does not have any actual interest for them: most countries do not have enough fund to afford even 5\% support of the value of the total agricultural production.

(2) Though reduction commitments of developing countries are permitted to be implemented a few years later, such schedule is based on politic bargaining but not real requirement of developing countries. The method which could really help developing countries is establishing the measure related the factors and essential of reduction commitments, in other words, but not dogmatic deadline.

Third, like we mentioned above, the benefits which brought by special and differential treatment for developing countries are impaired by the treatment of green and blue boxes for developed countries.

\section{Some reforms which should be considered}

In light of the developing countries' disappointment with the AoA, the WTO membership endorsed the idea of a 'development round' at Doha. It was supposed to give special consideration to the needs and concerns of developing countries. The Doha Declaration stressed that special and differential treatment for developing countries would be integral to the agricultural negotiations. However, the drafts submitted by US, EU and OECD are still disappointing and highly controversial. It was widely seen that the draft did not represent all members' interests fairly, and in particular was inadequate with respect to developing country concerns.

- Developing countries in particular are dependent on agriculture as a major source of employment and foreign exchange, and the AoA rules should be changed to allow these countries to nurture their domestic agricultural production and markets. Exemptions from tariff and domestic support reductions should be revised to take into account relative economic dependence and poverty. Market access.

Developing countries, especially poor members, should be allowed to limit market access, by the application of tariffs, quotas or variable levies, to protect the existence of agricultural systems that they can show provide environmental or other public goods. This would allow poor Members to take action to protect their environments and peasant farmers, when they do not have the fiscal resources to do so.

Tariff, special safeguard and tariff quotas are three important aspects of market access which should be considered to amend to meet the needs of developing countries. There are some suggestions about these aspects.

First, in order to keep food security and protect peasant farmers, developing countries should control imports of food directly. At the same time, AoA should allow developing countries to execute quantitative restrictions. When a country takes such measures, it should note the Secretariat of WTO and prepare to negotiate with other countries if they require.

The tariff cut commitment of products which related to food security should be abolished. When developing countries found the current tariff of a certain product could not protect peasant farmers, they can negotiate with interest concerned countries and ask for rise limited tariff. In such situation developing countries should not be asked for compensation.

AoA should give a 'top' tariff which could apply to all the products. That means the tariff of any product cannot be higher than the 'top' tariff. As the special and differential treatment, developing countries could have a higher 'top' tariff than developed countries.

There should be a certain proportion of the total agriculture tariff cut (such as at least a certain percent) and of every agriculture tariff cut during five years. At the same time, give developing countries lower proportion and longer time.

Second, there should be a provision that developing countries could execute special safeguard measure. Because it is complex to start the measure, the AoA should afford a simple standard of startup for developing countries. One possible way is if the import level exceeds a certain proportion of the average level of last three years, developing countries could execute special safeguard measure. The same way can be used in trigger price: when the price falls to a certain proportion of the average price of last several years, they can use the measure.

Third, except the tariff quotas for some special countries, there should be more tariff quotas that could be executed by all the members with transparence. In particular, tariff quotas should be used by export countries which actually implement non-discrimination policy.

- Domestic support.

First, the supports including in blue and green boxes should be restricted and cut as same as those in amber box. There 
must be a schedule of supports reducing: all the supports must be abolished before a certain time, and the proportion of supports reducing of every year should be set. Further more; domestic support should be restricted by Dispute Settlement Mechanism.

Second, in order to protect food security and peasant farmers, developing countries could afford domestic supports to products which for domestic consumption and peasant farmers. Such supports should not be restricted by Dispute Settlement Mechanism. To insure the supported products are only used for domestic consumption, only the non-exported products or the products which in the limitation of lowest export (a certain percent of products) could apply such supports. And the definition of peasant farmer should be determined by idiographic society and economic conditions of developing countries. The de minimis commitment of market access of developing countries should be abolished.

- Export subsidies.

First, all kinds of export subsidies, including export credit, export credit guarantee and export insurance, should be cancelled during a certain period or before a certain time. All countries should note WTO Secretariat about their plans and measures of export subsidies cutting so that Secretariat can supervise them effectively. The developing countries should be afforded a longer period.

Second, AoA should allow developing countries to execute export subsidies for high-tech agriculture products. There should be a top subsidy likes a certain percent of export price of product.

\section{Conclusion}

Among all the agreements of WTO, the most interested one to developing countries seems to be the AoA. To some extent, the reason that developing countries accept the agreement on TRIPS and GATS which does not have much benefit to them is because they expect to achieve the anticipated purpose in the field of agriculture. However, the actual situation is not so satisfying and it could even say they are cheated. The AoA ignores real differences among countries by suggesting that all nations can benefit from following varying degrees of the same liberalization policies. Worse, the agreement allows rich countries to buy themselves extraordinary exceptions to the rules, something developing countries cannot hope to do.

The basal problem of AoA is that it based on a hypothesis that the production and trade of agriculture can be operated under commercial condition. However, in most of developing countries the agriculture is not a commercial work. It is operated mainly by peasant farms and farmers, who living on farming not because of earning money but because the lands are owned by they for generations and they do not have other income. It is hard for them to face the international competition and may result to a large scale unemployment and breakdown of country economy. That leads the fact that the protection of agriculture in developing countries is even more important than that in developed countries. Therefore, when the AoA considering the restriction of applying protected provisions on agriculture in developing countries, it should be much caution and fair. The first thing should be considered is the particular situations of developing countries but not the political balance between them and developed countries.

\section{References}

Ataman, Aksoy, M. (2007). Global Agricultural Trade Policies. In Ataman and Beghin (Eds.), Global Agricultural Trade and Developing Countries. Washington, D.C.: World Bank.

Anderson, Kym and Martin, Will. (2007). Agricultural Trade Reform and the Doha Agenda. The World Economy, Vol.28, No.9, pp.263.

FAO. (2006). WTO Agreement on Agriculture: The Implementation Experience: Developing Country Case Studies (Rome: FAO). [Online] Available: www.fao.org/docrep/005/y4632e/y4632e00.htm (Dec.7, 2007).

IMF/World Bank paper. (2002). Market Access for Developing Country Exports- Selected Issues. [Online] Available: www.imf.org/external/np/pdr/ma/2002/eng/092602.pdf (Dec.7, 2007).

Clapp, Jennifer. (2006). WTO Agriculture Negotiations and the Global South. [Online] Available: http://www.yale.edu/envirocenter/clapp_paper.pdf (Dec.8, 2007).

Prema-chndra ATHUKORALA. (2007). Agricultural Trade Reforms in the Doha Round: A Developing Country Perspective. Journal of World Trade. 38 (5), pp.877-897. 
Table 1. Special and differential treatment in the AoA

\begin{tabular}{|c|c|c|c|}
\hline \multicolumn{2}{|l|}{ Measures } & Developed Countries & Developing Countries \\
\hline \multicolumn{2}{|l|}{ period } & 6 years & 10years \\
\hline \multirow{4}{*}{ Market access } & customs duties reduction & $36 \%$ & $24 \%$ \\
\hline & minimum per tariff line & $15 \%$ & $10 \%$ \\
\hline & opportunity & $5 \%$ & $4 \%$ \\
\hline & deadline & 2000 & 2005 \\
\hline \multirow{3}{*}{$\begin{array}{l}\text { Domestic } \\
\text { support }\end{array}$} & reduction in AMS & $20 \%$ & $13.3 \%$ \\
\hline & de minimis rule & $5 \%$ & $10 \%$ \\
\hline & exceptions & Blue and green boxes & $\begin{array}{l}\text { Blue boxes, green boxes and } \\
\text { three types in amber boxes. }\end{array}$ \\
\hline \multirow{3}{*}{$\begin{array}{l}\text { Export } \\
\text { subsidies }\end{array}$} & reduction in value & $36 \%$ & $24 \%$ \\
\hline & reduction in volume & $21 \%$ & $14 \%$ \\
\hline & exceptions & - & $\begin{array}{l}\text { Support for marketing and } \\
\text { domestic and international } \\
\text { transport }\end{array}$ \\
\hline
\end{tabular}

